DOI https://doi.org/10.18551/rjoas.2021-03.10

\title{
THE IMPLEMENTATION OF COVID-19 COUNTERMEASURES POLICY IN BANDUNG CITY, INDONESIA
}

\author{
Enang Koko \\ University of Nurtanio, Bandung, Indonesia \\ Afandi Muhamad Nur \\ Politeknik STIA LAN Bandung, Indonesia \\ `E-mail: kokoenang57@gmail.com
}

\begin{abstract}
The spread of Covid-19 is being taken seriously by the Bandung city government by issuing policy aimed at minimizing the impact it causes. This article is intended to analyze the implementation of the Covid-19 countermeasures policy in the city of Bandung. The research method used in this research is the descriptive research method with a qualitative approach. The results showed that the implementation of Covid-19 countermeasures policy in the city of Bandung which was analyzed using the theory from Edward III that the city government of Bandung has implemented Covid-19 countermeasures policy properly, which are aimed at the adequacy of government officials, good bureaucratic structures, and good communication, on the other hand, the government of Bandung City needs to improve the consistency and commitment of government officials regarding the disposition of the bureaucracy, so that government officials have a high commitment to consistently implement policy to deal with Covid-19 properly.
\end{abstract}

\section{KEY WORDS}

Covid-19, policy Implementation, government role.

Covid-19 has become a problem for many countries in the world. The virus that spread at the end of 2019 in the Chinese city of Wuhan has infected more than one hundred million people in many countries. Policy issued by governments in various countries in tackling Covid-19 differ from one another but can be grouped into two major policy, namely lockdown policy and social distancing policy (Fang, Weedon, \& Handley, 2020).

The lockdown policy is carried out by a country where the spread of Covid-19 has been very disturbing and has caused many casualties, with the policy of prohibiting people from doing activities in public spaces, it is hoped that it will be able to prevent the spread of Covid19 so that medical personnel will focus on treating patients who are infected with Covid-19 so that the Covid-19 pandemic is expected to be resolved quickly. The social distancing policy is mostly carried out by a country where the spread of Covid-19 can still be overcome by the government without prohibiting people from carrying out their activities in public spaces, social distancing policy is more about applying standard health protocols for the community when in public spaces (Herdiana, 2020).

Indonesia, as a country that has the most cases of infection compared to ASEAN countries, chooses a social distancing policy to tackle Covid-19, the government limits people's activities while in public spaces aimed at minimizing the spread of Covid-19 in public spaces, so there is a synergy between response to Covid-19 with sustainable community activities (Pemerintah Indonesia, 2020b).

The Indonesian government finally designated Covid-19 as a non-natural national disaster; COVID-19 was designated by the Indonesian government as a non-natural national disaster after many cases of Covid-19 infection occurred in various regions. Responding to the many cases of Covid-19 infection in various regions, various efforts have been made by the government as an effort to tackle Covid-19 starting from a policy aimed directly at tackling Covid-19 such as procurement of medical devices for medical personnel, to a policy 
aimed at helping people affected by Covid, such as social assistance policy for the poor. This policy has been implemented by the government with the hope that there will be a decrease in the number of Covid-19 causes and the people affected by Covid-19, especially the poor, can survive amid the spread of Covid-19 which has empirically caused losses both economically and socially (Pemerintah Indonesia, 2020a).

The city of Bandung as one of the cities that has the highest cases of Covid-19 infection in West Java Province has implemented various Covid-19 prevention policy which is expected to reduce the spread of Covid-19 in the city of Bandung so that the negative impact of Covid-19 in the city Bandung can be minimized. This was done as an effort to maintain economic growth so that people, especially the poor, can carry on their lives amid the spread of the Covid-19 pandemic. The Covid-19 control policy in Bandung City consists of various programs both aimed directly at efforts to tackle Covid-19, such as the provision of protective equipment specifically for medical personnel, as well as programs aimed at affected communities such as cash assistance and food delivery programs. This Covid-19 countermeasures policy is expected to be able to suppress the spread of Covid-19 in the City of Bandung and be able to help the economy of the people affected by Covid-19 (Prasetya, 2020).

Based on the explanation above, this article is intended to describe the implementation of the Covid-19 countermeasures policy carried out in the City of Bandung, how the implementation of the Covid-19 countermeasures policy has been carried out by the Bandung city government. The analysis was carried out using the theory of Edward III in which policy implementation was influenced by 4 (four) factors consisting of communication, resources, disposition and bureaucratic structure.

\section{LITERATURE REVIEW}

Public policy is basically whatever the government chooses or not chooses, which in the context of public policy, the government responds to existing public issues which will then become the policy taken by the government. On this basis, public policy is more often seen as a study that focuses on government actions in making policy concerning public interest (Jones, 1984; Perry \& Kingdon, 1985).

The public policy process examines how a policy is formulated from the start to produce a policy to be implemented which consists of a policy formulation process, a policy implementation process and a policy evaluation process. In the policy formulation process, issues in society are compiled and formulated to make policy, after the policy is formulated and ratified, the policy enters the implementation process where the policy is applied in society as the substance in the policy, then after the policy is implemented then an assessment will be carried out whether it succeeds or experiences failure, the process is known as public policy evaluation (Campbell, 2002; Rianto, 2010). Associated with the implementation of the Covid-19 countermeasures policy in the City of Bandung, then in this context, a theoretical study is used regarding the implementation of public policy in which a policy is implemented to be able to solve public problems that occur, in this case, Covid-19 countermeasures so that the existing problems are expected can be resolved properly.

Analysis of the implementation of Covid-19 countermeasures policy in the City of Bandung uses implementation theory from Edward III, where there are 4 (four) factors that determine policy implementation, namely communication, resources, disposition and bureaucratic structures can be implemented properly (Akib, 2010; Winarno, 2002), the analysis uses understanding from Edward III is expected to bring up what factors are driving and hindering the implementation of the Covid-19 countermeasures policy that is being implemented by the city government of Bandung.

\section{METHODS OF RESEARCH}

The research method used in this article is a descriptive research method with a qualitative approach. The use of this research method is by the research objectives which 
want to describe and analyze the implementation of the Covid-19 countermeasures policy in the city of Bandung. This is in line with the understanding of various experts such as the understanding from (Sugiyono, 2013) which states that descriptive research with a qualitative approach analyzes problems based on narrative word descriptions and not in the form of research that presents statistical data results. Associated with the problem of implementing the Covid-19 countermeasures policy in the City of Bandung, the analysis is carried out in a narrative form in the form of words obtained both from informants and from secondary reference sources such as books, journal articles and other relevant documents.

The data in this study comes from primary data obtained from informal information about the implementation of the Covid-19 prevention policy in Bandung and secondary data taken from books, journal articles and other documents. The data is then analyzed data through a data presentation process consisting of data collection, data display and concluding as stated by Creswell (2007). The data triangulation process is carried out through a check, re-check and cross-check where the data that has been obtained are sorted to produce valid and correct data.

\section{RESULTS AND DISCUSSION}

Covid-19 was originally discovered in the Chinese city of Wuhan around the end of 2019 , this virus has spread rapidly to various countries to the point where more than a hundred million people have been infected with Covid-19 and there have been more than two million people who have died until February 2021. Covid-19 in Indonesia began to occur since the beginning of March 2020 when the first case of Covid-19 infection was discovered, since then Covid-19 has spread rapidly to various areas where it was reported that many people were infected with Covid-19, based on the spread of Covid-19 which so fast, the government has taken the various policy to anticipate the widespread spread of Covid-19.

The city of Bandung as the capital of the province of West Java takes the spread of Covid-19 seriously, the government issued a policy instrument intended for prevention, at the beginning of the spread of Covid-19 a policy of closing schools and offices was implemented, this was intended to minimize human interaction, in the next stage a PSBB policy was implemented (Large-Scale Social Restrictions), which in the implementation of the PSBB policy various community activities ranging from school activities, offices to markets are closed or restricted. The implementation of the PSBB has had a lot of impact on the economy of the community where many people cannot make a living due to restrictions, therefore the government, both the central government and the city government of Bandung, has launched a social assistance policy specifically for people affected by Covid-19, this assistance starts from assistance cash directly to basic foodstuffs to assistance (Hakim, 2020b; Humas Setda Subang, 2020).

The Bandung city government is promoting a campaign using masks and maintaining distance when in public spaces, this policy was carried out to minimize the spread of Covid19 in public spaces. The policy that is directly aimed at tackling Covid-19, such as the procurement of medical masks and personal protective equipment, are carried out to protect medical personnel who treat Covid-19 patients. The various programs which are part of the Covid-19 prevention policy carried out by the Bandung City government are expected to be able to minimize the spread of Covid-19 in the City of Bandung so that they can return to restore community activities that during the Covid-19 pandemic were disturbed (Hakim, 2020a).

Analysis of the implementation of the Covid-19 countermeasures policy in the City of Bandung was carried out using the theory of public policy implementation from Edward III, in which the implementation of public policy will run well if factors such as communication, resources, disposition and bureaucratic structures can be implemented properly (Winarno, 2002). The detailed analysis can be explained as follows:

First, the communication aspect. Communication means the process of delivering messages or information carried out by communicators to communicants, from this understanding three main elements must be present in communication, namely the presence 
of a communicator, the presence of a communicant and a message to be conveyed, so the message conveyed will be well received by the communicant which is expected the communicant to behave as desired by the communicator through the message that has been conveyed (Rianto, 2010).

Communication in the context of public policy implementation according to Edward III is the process carried out so that the stakeholders or actors involved know about the substance of the policy that has been made so that these stakeholders can know their respective roles and duties which are expected to contribute to the success of policy implementation.

Communication in the context of implementing the Covid-19 countermeasures policy in the City of Bandung means how the Bandung City government as a government institution that has the authority in implementing policy communicates or delivers messages to both government officials in Bandung City and the public regarding the Covid-19 countermeasures policy that occurred in the City of Bandung.

The purpose of implementing communication regarding Covid-19 prevention policy in the City of Bandung, namely: The first aspect, the existence of Bandung City government officials who have knowledge and understanding of the substance of the Covid-19 countermeasures policy so that in carrying out their duties and responsibilities the apparatus in the city government of Bandung have competences in their respective fields, so they are expected to contribute to the successful implementation of the Covid-19 countermeasures policy in the City of Bandung.

The second aspect, the expected goal of the communication made regarding the implementation of the Covid-19 countermeasures policy is for the public to know and understand the implementation of the Covid-19 countermeasures policy so that the public will comply with the Covid-19 countermeasures policy which has become government policy and the public will have the awareness to actively participate in the successful implementation of the Covid-19 countermeasures policy in the City of Bandung.

The results of research regarding the communication of the implementation of the Covid-19 countermeasures policy in the City of Bandung can be explained as follows: First, the communication carried out internally for the Bandung city government apparatus can be said to be going well. Government officials in the City of Bandung already know about the Covid-19 countermeasures policy which is a policy that must be implemented in Bandung City.

Government officials have implemented Covid-19 countermeasures properly in accordance with their respective duties and roles. The Bandung City Government ensures that existing government officials can carry out their duties, both directly aimed as medical and non-medical officers who will directly face Covid-19 countermeasures in Bandung, as well as officers who do not directly deal with Covid-19 in the city of Bandung, such as government officials in the Bandung City government office environment.

The problem that arises in the communication of the implementation of the Covid-19 countermeasures policy in the City of Bandung is the limitation of physical meetings, this is due to the work from the home policy so that direct communication is not possible to ensure that all Bandung City government officials have good understanding and abilities in the implementation phase of the Covid-19 countermeasures policy in the City of Bandung.

The alternative to the limitations of physical meetings by the Bandung City government officials is responded to by intensifying online meetings where communication is done more intensely through applications such as WhatsApp and telegram, this is considered capable of encouraging the understanding of Bandung City government officials and able to improve the quality of work of Bandung City government officials in order to implement the Covid-19 countermeasures policy in Bandung City.

Another aspect is the communication of the implementation of the Covid-19 countermeasures policy carried out to the public. The public is the target in implementing the Covid-19 countermeasures policy where the community will be the key to the successful implementation of Covid-19. The existence of a good understanding aimed at the community and obedience to the implementation of the Covid-19 policy will be a driving force for success in implementing the Covid-19 countermeasures policy, on the other hand, if the 
community has a low understanding and is aimed at least people who comply with the Covid19 countermeasures policy, then the policy implementation Covid-19 which is implemented in Banduk City will not succeed or it can be said that it will fail.

The communication made by the Bandung City government in implementing the Covid19 countermeasures policy can be said to be good, meaning that the Bandung city government has socialized the Covid-19 handling policy to the people in Bandung City with the hope that the community can understand and comply with the policy which is ultimately the case. Covid-19 infections in Bandung can be minimized.

The problem that occurs in the communication of Covid-19 implementation policy in the City of Bandung is that there are still people who do not know about the Covid-19 countermeasures policy, there are even people who know about the existence of Covid-19 countermeasures policy in Bandung City but deliberately violate this policy, such as there are residents who do not use mouth masks when in public spaces. This condition ultimately causes the implementation of the Covid-19 countermeasures policy in the aspect of communication to the public to be not optimal because there are people who deliberately violate the Covid-19 countermeasures policy.

The condition of the problems that arise in the implementation of the Covid-19 prevention policy in Bandung City in the communication aspect needs to be the attention of the Bandung City local government, where the Bandung City local government must increase work intensity in communicating with various parties related to the implementation of Covid19 countermeasures policy, information regarding the Covid-19 policy can be well received, and it is also hoped that all parties who are stakeholders can contribute according to their respective roles.

The second, the Resource Aspect. Resources are one of the most important aspects of an organization, the existence of good resources will encourage the organization towards improvement, on the other hand, if the organization has limited resources it will be difficult for the organization to achieve its organizational goals. Based on this understanding, in the context of implementing the resource policy, it is the part that will determine the success or failure of the implementation of the policy (Soekidjan, 2009).

Resources have many aspects ranging from human resources to ownership of capital or money, in the context of implementing the Covid-19 countermeasures policy in the City of Bandung, according to the authors, the important resources that will determine the success of implementing the Covid-19 countermeasures policy in Bandung City consist from human resources, in this case, the resources of the Bandung City government apparatus and the budget, in this case, the Bandung City regional budget, to finance the implementation of the Covid-19 countermeasures policy in Bandung City. The detailed explanation can be explained as follows:

The first aspect, human resources, in this case, the Bandung city government apparatus, which in terms of quantity the Bandung city government apparatus has a sufficient number of government officials, but in the context of implementing the Covid-19 countermeasures policy that needs to be considered, namely government officials who are directly dealing with Covid-19 response, both medical personnel such as doctors and nurses, as well as non-medical personnel such as health educators who are tasked with disseminating Covid-19 response policy.

The results showed that the implementation of the Covid-19 countermeasures at the time of its initial implementation experienced a shortage of medical personnel, where the medical personnel needed still had shortages, especially medical doctors. Another problem with medical personnel is the inadequacy of medical equipment used by doctors and nurses, such as hazmat suits and mouth masks. This condition ultimately disrupts the performance of doctors and nurses in providing services to patients suffering from Covid-19.

The central government responded to this problem by holding additional volunteers, both medical and non-medical, who will work to tackle Covid-19, this effort is considered successful so that the adequacy of medical and non-medical personnel can be fulfilled so that health services for patients suffering from Covid -19 can be done optimally. 
The second aspect is the Covid-19 countermeasures budget. The budget is part of the key to success for local government officials in implementing the Covid-19 countermeasures policy. In general, the budget for dealing with Covid-19 in Bandung is sufficient. This is aimed at the availability of the budget needed to finance various Covid-19 countermeasures, with an adequate budget, the local government of Bandung City can implement Covid-19 countermeasures policy properly.

The government of Bandung must respond to the adequate Covid-19 response by utilizing the existing budget efficiently, the existing budget must also be accounted for by existing regulations. This is to prevent acts of corruption against the costs of implementing the Covid-19 countermeasures policy in Bandung City.

Based on this understanding, the Bandung City government must be able to synergize between the Covid-19 countermeasures policy with the Covid-19 countermeasures budget, so that it will bring out the compatibility and synergy between the Covid-19 countermeasures policy and its budget which is expected to eventually be able to produce a Covid-19 countermeasure policy which can not only be carried out well but can also have an impact on the good of the community, especially for the poor who are affected by Covid- 19 .

Third, the disposition aspect. According to Edward III, what is meant by disposition is the characteristics attached to the implementor such as honesty, commitment and democracy. In the context of implementing the Covid-19 countermeasures policy, what is meant by disposition is the character of the bureaucratic apparatus, in this case, the Bandung City government apparatus is committed to the successful implementation of the Covid-19 countermeasures policy in Bandung City.

Based on the results of the research conducted shows that the Bandung city government apparatus is committed to the successful implementation of the Covid-19 prevention policy in Bandung, this is shown that the Bandung City government apparatus has a direct task in overcoming Covid-19 are working according to their duties, so that as a whole able to work as a duty as stipulated in the regulations regarding the Covid-19 countermeasures policy.

Other government officials such as employees at the Bandung City government office commit to tackling Covid-19 which is shown by following instructions as issued by the mayor of Bandung, such as working at home or for officers working in offices must still adhere to health protocols such as wearing mouth masks and keep the distance.

The efforts that have been made show that the city government of Bandung has a good commitment in its efforts to implement Covid-19 countermeasures policy which are expected to be able to reduce the spread of Covid-19 but will also be able to overcome the impact of Covid-19 on people's lives, especially for the poor, wherewith the Covid-19, the poor have difficulty earning a living for their families.

Fourth, the bureaucratic structure. According to Edward III, the bureaucratic structure relates to the procedures and rules regarding the implementation of a policy, in another aspect it is also called the SOP (standard operational procedure) which regulates in detail what kind of policy can be implemented including the duties of the actors involved. The bureaucratic structure associated with the implementation of the Covid-19 countermeasures policy in the City of Bandung is closely related to how detailed the regulations issued by the Bandung city government regarding the Covid-19 countermeasures policy, which must be operational which can be used as guidelines for executors, in this case, the apparatus Bandung city government in implementing Covid-19 countermeasures policy, so that the implementation of Covid-19 countermeasures policy can run successfully as the initial goal has been set.

The implementation of the Covid-19 countermeasures policy in the City of Bandung generally has a clear SOP, in the sense that every Covid-19 prevention policy program starting from the Covid-19 countermeasures program directly to the Covid-19 infected community and the affected community already has an SOP. Every program related to the Covid-19 countermeasures policy can be carried out well where government officials have an understanding of the SOPs that regulate the duties of each apparatus in the effort to tackle Covid-19. 
A problem in implementing Covid-19 countermeasures policy in the City of Bandung is because the transmission of Covid-19 is developing rapidly, so that several programs in dealing with Covid-19 change quickly too, in an empirical context, these changes sometimes also change the substance of the Covid-19 countermeasures policy. For example, when the City of Bandung implemented the PSBB policy, the policy only lasted for a few weeks, then it was changed back into a new policy such as PPKM (Restriction of Micro Scale Activities). The existence of policy changes carried out in a short time in the end directly not only has an impact on government officials who have to quickly adapt to a new policy, but also have an impact on society where people must also immediately adjust to a new policy and implement policy as decisions from the government.

Based on the aforementioned problems, the consistency of policy carried out by the Bandung City government is necessary; this is at least based on several considerations, namely: First, providing certainty to government officials in the City of Bandung regarding the tasks and jobs that must be carried out by each of these regulations in the context of dealing with Covid-19. Second, provide certainty to the public regarding the Covid-19 prevention policy that must be implemented in the city of Bandung. Third, provide certainty about the seriousness of the government in its efforts to tackle Covid-19 so that it will be able to create optimism that the Covid-19 countermeasures policy is correct and will succeed as the initial goals set.

The problem of changing Covid-19 countermeasures policy in a relatively fast time is also not only carried out by the Bandung City government, but also by the central government where the central government policy will become a policy that applies also to all cities including in the city of Bandung. Finally, the consistency of the central government in implementing the Covid-19 countermeasures policy will also influence the process of implementing prevention policy at the local level, including in the city of Bandung.

\section{CONCLUSION}

The Covid-19 countermeasures policy implemented in the city of Bandung, in general, can be said to be running well, this can be explained as follows: First, the communication where the Bandung City government has communicated well regarding the Covid-19 countermeasures policy, the Bandung city government has socialized Covid-19 prevention policy both internally to Bandung city government officials, and the community. Second, the resources for which the city of Bandung already has sufficient government apparatus, both in quality and quality, can implement policy to tackle Covid-19 in Bandung City. Third, the position in which the Bandung city government apparatus has a commitment and seriousness to contribute to the successful implementation of the Covid-19 countermeasures policy in Bandung City. Fourth, the bureaucratic structure where the city government of Bandung already has a good bureaucratic structure where the Bandung city government apparatus can work as the task that has been given.

The results also show that the city government of Bandung should maintain its commitment and consistency in efforts to tackle Covid-19 so that the public will see the seriousness of what the Bandung City government is doing in tackling the spread of Covid-19 in the city of Bandung. Based on the results of this study, is necessary further research that examines the implementation of Covid-19 countermeasures policy in the City of Bandung which is reviewed from various aspects such as from economic, social and other aspects to produce a complete picture of the implementation of Covid-19 countermeasures policy, which in the end can be used material for consideration for the city government of Bandung in compiling policy to tackle Covid-19 in the City of Bandung to accelerate the recovery process after the Covid-19 pandemic in Bandung City.

\section{REFERENCES}

1. Akib, H. (2010). Implementasi Kebijakan: Apa, Mengapa dan Bagaimana. Jurnal Administrasi Publik, 1(1), 1-11. 
2. Campbell, J. L. (2002). Ideas, Politics, and Public Policy. Annual Review of Sociology. https://doi.org/10.1146/annurev.soc.28.110601.141111.

3. Creswell, J. W. (2007). Qualitative Inquiry and Research Design: Choosing Among Five Approaches. Thousand Oaks: Sage Publications.

4. Fang, Ja., Weedon, A., \& Handley, E. (2020). Coronavirus COVID-19's Wuhan Lockdown: A Month On.

5. Hakim, R. N. (2020a). Kepala Bappenas Sebut Syarat "New Normal" Tak Hanya Turunnya Penularan Covid-19. Retrieved August 5, 2020, from https://nasional.kompas.com/read/2020/05/28/00160071/kepala-bappenas-sebut-syaratnew-normal-tak-hanya-turunnya-penularan-covid.

6. Hakim, R. N. (2020b). Saat Pemerintah Persiapkan Fase New Normal di Tengah Pandemi Covid-19. Retrieved September 7, 2020, from https://nasional.kompas.com/read/2020/05/27/08141631/saat-pemerintah-persiapkanfase-new-normal-di-tengah-pandemi-covid-19.

7. Herdiana, D. (2020). Konstruksi Konsep Social Distancing Dan Lockdown Dalam Perspektif Kebijakan Publik. Inovasi Pembangunan: Jurnal Kelitbangan, 8(2), 107-107.

8. Humas Setda Subang. (2020). Penyaluran Bantuan Sosial Prov Jabar Bagi Masyarakat Terdampak Covid-19. Retrieved September 21, 2020, from https://jabarprov.go.id/index.php/news/37582/2020/04/26/Penyaluran-Bantuan-SosialProv-Jabar-Bagi-Masyarakat-Terdampak-Covid-19

9. Jones, C. O. (1984). An Introduction to the Study of Public Policy (Third Edit). California: Brooks/ Cole Publishing.

10. Pemerintah Indonesia. Keputusan Presiden Nomor 12 Tahun 2020 tentang Penetapan Bencana Non-Alam Penyebaran COVID-19 sebagai Bencana Nasional (2020). Indonesia.

11. Pemerintah Indonesia. Peraturan Pemerintah Nomor 21 Tahun 2020 Tentang Pembatasan Sosial Berskala Besar dalam Rangka Percepatan Penanganan Corona Virus Disease 2019 (COVID-19) (2020). Indonesia.

12. Perry, J., \& Kingdon, J. W. (1985). Agendas, Alternatives, and Public Policies. Journal of Policy Analysis and Management. https://doi.org/10.2307/3323801.

13. Prasetya, E. (2020). Dampak Covid-19 Sangat Dirasakan Masyarakat, Apalagi Diberlakukan PSBB. Retrieved September 22, 2020, from https://www.merdeka.com/peristiwa/dampak-covid-19-sangat-dirasakan-masyarakatapalagi-diberlakukan-psbb.html.

14. Rianto, P. (2010). Opini Publik, Agenda Setting dan Kebijakan Publik. Jurnal Komunikasi, $5(1), 31-40$.

15. Soekidjan. (2009). Manajemen Sumber Daya Manusia. Jakarta: Bumi Aksara.

16. Sugiyono. (2013). Metode Penelitian Pendidikan Pendekatan Kuantitaif, Kualitatif, dan R\&D. Bandung: Alfabeta.

17. Winarno, B. (2002). Teori dan Proses Kebijakan Publik. Yogyakarta: Media Pressindo. 